\begin{tabular}{rl|l} 
Cellular Physiology & \multicolumn{1}{l}{\begin{tabular}{l} 
Cell Physiol Biochem 2012;30:151-159 \\
\cline { 2 - 3 } and Biochemistr.1159/000339054
\end{tabular}} & \multicolumn{1}{l}{$\begin{array}{l}\text { O 2012 S. Karger AG, Basel } \\
\text { www.karger.com/cpb }\end{array}$} \\
\cline { 2 - 3 } Published online: June 18, 2012 & Accepted: May 02, 2012 & $1015-8987 / 12 / 0301-0151 \$ 38.00 / 0$
\end{tabular}

\title{
Inorganic Phosphate Stimulates Fibronectin Expression in Renal Fibroblasts
}

\author{
Zhonghai Chen ${ }^{1}$ Dong Chen ${ }^{1}$ Thomas L. McCarthy ${ }^{2}$ Michael Centrella ${ }^{2}$ \\ Yuning Zhang ${ }^{1} \quad$ Gilbert W. Moeckel ${ }^{1}$ \\ Department of Pathology ${ }^{1}$ and Department of Surgery², Yale University School of Medicine, New Haven
}

\author{
Key Words \\ Fibroblast $\bullet$ Akt $\bullet$ Osterix $\bullet$ Fibronectin $\cdot$ NFATc1 $\bullet$ c-fos
}

\begin{abstract}
Elevated plasma phosphate levels are signifcantly associated with progression of chronic kidney disease (CKD). Interstitial fibrosis is an important factor in the progression of CKD. In this study we investigate the role of inorganic phosphate in stimulating fibronectin (FN) synthesis in a kidney fibroblast cell line (NRK-49F). We find that phosphate increases FN abundance and message in a dose-dependent fashion and that both ERK1/2 and AKT are important signaling pathways that mediate phosphate-dependent FN expression in NRK-49F cells. Moreover phosphate srimulates the expression of the transcription factors osterix and NFATc1, which form complexes and mediate FN synthesis. Another transcription factor involved in phosphatedependent FN synthesis is the AP1 family member c-Fos. In summary we show that even mildly elevated serum phosphate levels can induce synthesis of the interstitial matrix protein fibronectin through activation of ERK1/2 and AKT signaling pathways in kidney fibroblasts and that the synthesis of fibronectin is mediated by a transcriptional complex consisting of NFATC1, osterix and c-Fos.
\end{abstract}

\section{Introduction}

Copyright @ 2012 S. Karger AG, Basel

Chronic kidney disease (CKD) is a highly prevalent health problem with a rising incidence and a strong tendency for progression [1]. Increase in interstitial fibrosis of the kidneys is significantly associated with progression of CKD [2]. Elevated plasma phosphate levels have been shown to be an independent risk factor for a more accelerated decline in renal function in patients with chronic kidney disease (CKD) and in pre-dialysis patients [3]. The benefit of a low phosphate diet in slowing progression of CKD has been shown in humans and controlling phosphate retention is a key component in preventing disease progression in patients with CKD $[4,5]$. Preservation of renal function in patients with CKD postpones the onset of dialysis and is associated with increased patient survival [6]. A direct association between plasma phosphate concentration, morphologic changes such interstitial fibrosis in 
kidneys and decline in renal function has been shown in rats fed with a high phosphate diet $[7,8]$. However, the cellular and molecular mechanisms that mediate phosphate-dependent renal interstitial fibrosis have not been elucidated to date.

The bulk of plasma inorganic phosphate (Pi) is filtered at the glomerulus and reabsorbed in the kidney proximal tubule, which represents an important rate-limiting step in $\mathrm{Pi}$ homeostasis [9]. Inorganic phosphate has been shown to be an important mediator capable of enhancing expression of pivotal genes that regulate complex cellular processes such as gene transcription, signal transduction and cell cycle regulation [10]. One signaling molecule that mediates diverse extracellular stimuli induced by hormones, growth factors and extracellular matrix components is the serine/threonine kinase Akt1/protein kinase B. Akt stimulates the mammalian TOR signaling pathway and a recent study showed that the mTOR pathway was activated by inorganic phosphate [11]. Extracellular signal-regulated kinase (ERK) mediates signal transduction responses to many environmental stresses and has been shown to be activated in brain cells of developing mice following exposure to high inorganic phosphate diet [12]. However, the signaling pathways induced by Pi in kidney fibroblasts and their role in stimulating fibrogenic molecules in kidney fibroblasts are unknown.

Osterix is a novel zinc finger-containing transcription factor of the SP gene family that plays an important part in osteoblast differentiation [13]. The human orthologue of the mouse Osterix (Osx/SP7) gene has been isolated and contains two exons, which are highly conserved between the two species [14]. Osterix has been shown to act as a transcriptional activator in several different cell lines [15]. High Pi levels have been shown to induce Osterix in other non-skeletal tissue, such as vascular smooth muscle cells in mice [16]. Osterix binds to Sp1-like sequences in the Col1 $\alpha 1$ and $\operatorname{Col} 2 \alpha 1$ promoters and has been shown to stimulate the synthesis of Col5 $\alpha 1$. Therefore we hypothesized that high phosphate concentrations induce Osterix expression in kidney fibroblasts and stimulate the synthesis of the matrix protein fibronectin.

The nuclear factor of activated T cells (NFATc) proteins are a family of transcription factors whose activation is mediated by calcineurin. Four distinct genes that encode closely related NFATc proteins (NFATc1-4) [17] have been identified and are involved in multiple biological processes ranging from lymphocyte activation to cardiac hypertrophy [18]. The transcription factors of the NFAT family act synergistically with AP-1 (Fos/Jun) proteins to form stable transcriptional complexes which regulate expression of diverse genes [19]. One of the NFAT transcription factors, NFATc1 has been shown to form a transcriptional complex with osterix thus mediating the synthesis of bone matrix formation in osteoblasts [20]. A recent study showed that NFATc1 stimulates fibronectin synthesis through transcriptional activation in mesangial cells [21]. We therefore hypothesized that osterix and NFATc1 act synergistically to mediate phosphate-dependent synthesis of fibronectin in kidney fibroblasts.

In this study, we asked whether elevated culture medium phosphate levels stimulate the synthesis of interstitial matrix proteins such as fibronectin (FN) in kidney fibroblasts and which transcription factors and signaling pathways are activated by high phosphate treatment. Our results show that phosphate exposure activates ERK1/2 and Akt1 signaling pathways and stimulates the abundance and expression of the transcription factors NFATc1, c-fos and Osterix, which mediate fibronectin expression in a renal fibroblast cell line (NRK49F).

\section{Materials and Methods}

Reagents and anti-bodies

Inorganic Phosphate $\left(\mathrm{NaH}_{2} \mathrm{PO}_{4}\right.$ and $\mathrm{Na}_{2} \mathrm{HPO}_{4}$ ) was obtained from American Regent, Inc (Shirley, NY, USA). 3-(4, 5-dimethylthiazol-2-yl)-2, 5-diphenyl tetrazolium bromide (MTT) and Osterix small interfering RNA (siRNA) were purchased from Sigma (St. Louis, MO, USA). Anti-fibronectin antibody was obtained from 


\begin{tabular}{|c|c|c|}
\hline Cellular Physio & Cell Physiol Biochem 2012;30:151-159 & \\
\hline and Riochemistr & $\begin{array}{l}\text { DOI:10.1159/000339054 } \\
\text { Published online: June 18, } 2012 \\
\end{array}$ & $\begin{array}{l}\text { (c) } 2012 \text { S. Karger AG, Basel } \\
\text { www.karger.com/cpb }\end{array}$ \\
\hline
\end{tabular}

Rockland (Gilbertsville, PA), anti-Osterix antibody from Abcam (Cambridge, MA)), anti- $\beta$-actin antibody (Sigma, MO), anti-Akt1 antibody, anti-erk1/2 antibody and anti-p-ERK1/2 antibody were obtained from Santa Cruz (Santa Cruz, CA, USA). Anti-p-Akt S473 antibody, anti-p-PI3K p85Y458 and LY294002 were purchased from Cell Signaling Technology (Beverly, MA).

\section{Cell culture}

Rat kidney fibroblast NRK-49F cell line was obtained from American Type Culture Collection (CRL1570). Cells were maintained in Dulbecco's modified Eagle's medium (DMEM) supplemented with 10\% bovine serum (GIBCO), 1\% non-essential amino acid, penicillin (100 unit $/ \mathrm{ml})$, and streptomycin $(100 \mu \mathrm{g} /$ $\mathrm{ml}$ ). Cells were incubated in $95 \%$ air, $5 \% \mathrm{CO}_{2}$ humidified atmosphere at $37^{\circ} \mathrm{C}$. NRK- $49 \mathrm{~F}$ cells were treated with 1.25 (control), 2.5 and $5.0 \mathrm{mM}$ of phosphate $\left(\mathrm{NaH}_{2} \mathrm{PO}_{4}\right.$ and $\left.\mathrm{Na}_{2} \mathrm{HPO}_{4}\right)$ for 30 or 60 minutes in signaling experiments and for 48 hours in all other experiments.

Real-time polymerase chain reaction (RT-PCR)

Total RNA was isolated using an RNA extraction kit (Rneasy, Qiagen) in accordance with the manufacturer's instructions. First-strand cDNA synthesis was accomplished using a SuperScript First-Strand Synthesis System for RT-PCR (Invitrogen, Carlsbad, CA). Real-time PCR was performed in triplicate with Power SYBR Green PCR (ABI, Carlsbad, CA) according to the manufacturer's protocol. All PCR amplifications were carried out using ABI 7300 real-time cycler (ABI, Carlsbad, CA). The expression of target genes was normalized to the expression of $\beta$-actin. Relative gene expression level (the amount of target, normalized to endogenous control gene) was calculated using the comparative Ct method formula 2- $\Delta \Delta \mathrm{Ct}$. [22]

\section{Western blot analysis}

Cells were lysed at $4^{\circ} \mathrm{C}$ in RIPA buffer containing $50 \mathrm{mM}$ Tris- $\mathrm{HCl}$ (pH 7.4), $150 \mathrm{mM} \mathrm{NaCl}, 1 \%$ Triton X100, 0.25\% Sodium deoxycholate, 5 mM EDTA (pH 8.0), and 1 mM EGTA and supplemented with protease and phosphatase inhibitors. After 20 min of lysis on ice, cell debris was removed by microcentrifugation, followed by quick freezing of the supernatants. The protein concentration was determined by Bradford method [23]. Equal amounts of proteins were separated by SDS-polyacrylamide gels and then electrophoretically transferred from the gel onto a PVDF membrane (Millipore, Bedford, MA). After blocking with 5\% nonfat milk, the membrane was reacted with specific primary antibodies overnight at $4^{\circ} \mathrm{C}$ and then incubated with horseradish peroxidase conjugated secondary antibody for $1 \mathrm{~h}$. The blots were visualized using ECLPlus detection kit (Perkin Elmer Life Sciences, Inc. Boston, MA, USA). The blot images were quantitated by densitometry using the Image J analysis software and normalized with the internal control ( $\beta$-actin) [24].

\section{Cell proliferation assay}

Cell proliferation were assessed by the mitochondrial-dependent reduction of MTT to purple formazan. After culture of overnight in a 96-well plate, NRK-49F cells $(1 \times 104$ cells/well) were treated with $1.25,2.5$ and $5.0 \mathrm{mM}$ of phosphate. After 48 hours treatment, MTT solution $(100 \mu \mathrm{g} /$ well $)$ was added for another 2 hours. The medium was removed and $200 \mu \mathrm{l}$ of DMSO was added to each well and then vibrated for 10 min. Absorbance at $550 \mathrm{~nm}$ was measured using a microplate reader. The percentage of viable cells was calculated as follows: (absorbance of experimental group/absorbance of control group) x 100\%.

\section{Luciferase Reporter Assay}

NRK-49F cells were co-transfected with a fibronectin promoter driven luciferase construct and firefly luciferase reporter vector (Promega, Madison, WI) using Lipofectamine 2000 reagent and then treated with phosphate for another 24 hours. After the treatments, cells were washed once with ice-cold phosphatebuffered saline and lysed with $100 \mu \mathrm{l}$ of lysis buffer, and the cell extracts were collected into microcentrifuge tubes. Luciferase activity was measured 24 hours after transfection using a Dual-Luciferase Reporter Assay System (Promega) and FarCyte Tecan Ultra Plate Reader (Amersham Pharmacia, Piscataway, NJ). Relative luciferase activity was calculated by normalizing the firefly luminescence as to the renilla luminescence.

\section{Transfection efficiency}

NRK-49F cells were seeded at 200,000 cells per well in 6-well plates in $2 \mathrm{~mL}$ of growth medium composed of Dulbecco's modified Eagle's medium (DMEM; Sigma, St. Louis, MO, USA) supplemented with $10 \%$ fetal bovine serum and $1 \%$ penicillin/streptomycin (GIBCO/Invitrogen, Grand Island, NY, USA). Cells were incubated overnight at $37^{\circ} \mathrm{C}$ and $5 \% \mathrm{CO}_{2}$. The following morning, $2 \mu \mathrm{g}$ of plasmid DNA (pEGFP-C2 (Clontech)) was diluted into OPTIMEM (Life Technologies) and mixed with $5 \mu$ l of Lipofectamine 2000 (Life Technologies) according to manufacturer's instructions. Prior to transfection, the growth medium was replaced with $2 \mathrm{ml}$ of OPTIMEM. DNA-Lipofectamine complexes were added to the cells and incubated for 6 hours. The transfection medium was then replaced by growth medium and cells were incubated for an additional 24-48 hours. Transfection efficiency was monitored by fluorescence microscopy. 


\section{Cellular Physiology Cell Physiol Biochem 2012;30:151-159

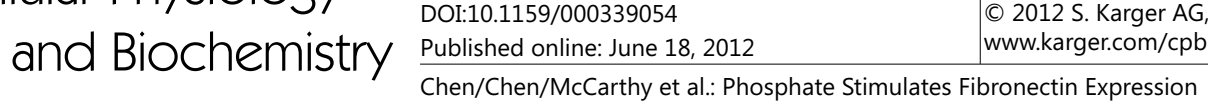

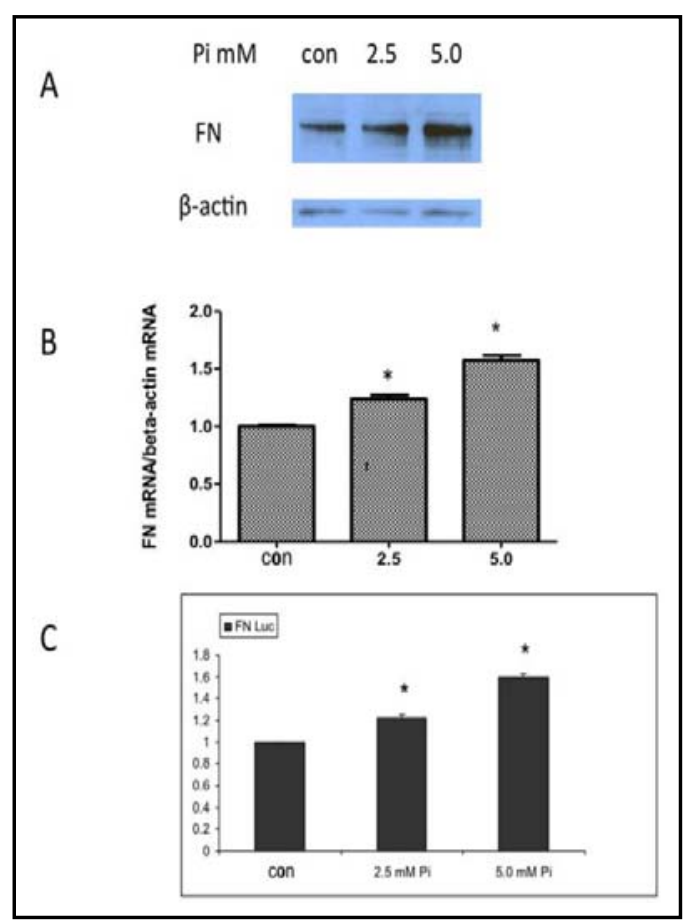

Fig. 1. A: Fibronectin abundance was increased in renal fibroblast (NRK-49F cells) following exposure to 2.5 and $5.0 \mathrm{mM}$ phosphate medium concentration. B: Fibronectin mRNA increased by $25 \%$ at $2.5 \mathrm{mM}$ and $60 \%$ at $5 \mathrm{mM}$ phosphate treatment. C: Transfection of NRK-49F cells with a fibronectin promoter construct showed dosedependent increase in FN promoter activity by phosphate treatment. *, $\mathrm{p}<0.05$ compared to control medium.

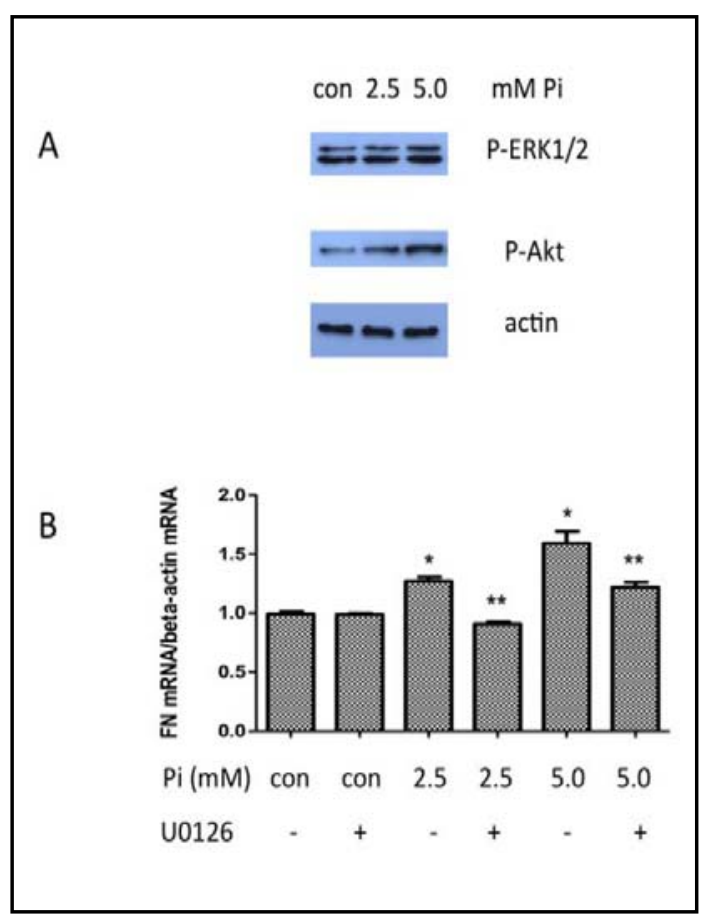

Fig. 2. A: Treatment of renal fibroblast with 2.5 and $5.0 \mathrm{mM}$ phosphate stimulated ERK1/2 and AKT1 phosphorylation. B: Pretreatment of NRK $49 \mathrm{f}$ cells with ERK1/2 inhibitor U0126 inhibited the phosphate-dependent increase in fibronectin mRNA by $110 \%$ in the $2.5 \mathrm{mM}$ Pi group and by $45 \%$ in the $5.0 \mathrm{mM}$ Pi group. *, p<0.05 compared to control medium. **, $\mathrm{p}<0.05$ compared to same medium phosphate concentration but without U0126.

Small interfering RNA (siRNA) transfection

Cells were seeded in 6-well plates and transfected with Osterix specific siRNA using Lipofectamine 2000 (Invitrogen) in accordance with the manufacturer's instructions. After 6 hours of incubation, the medium was replaced with complete medium. Rat osterix siRNA (SASI_Rn01_00102434) was purchased from Sigma. siRNA sequences were as follows: 5'- GUCUACACGUCCUUGGAUAdTdT -3' (sense) and 5'UAUCCAAGGACGUGUAGACdTdT -3' (antisense).

\section{Immunoprecipitation and Western Blot}

Cell extracts were treated with pre-immune IgG or Anti-NFATc1 antibody (sc-7294, Santa Cruz Biotech) and the immune precipitates were collected using a Protein A agarose column (Santa Cruz). Total cell extract or immune precipitates were fractionated by electrophoresis on a 10\% SDS-polyacrylamide gel, blotted onto nitro cellular membranes (Bio-Rad), probed with anti-Osterix antibody (Ab22552, Abcam), and visualized with secondary antibody and chemiluminescence.

Statistical analysis

All data are presented as mean \pm S.D. Statistical analysis used Student's t-test for pairs with the following significance levels: ${ }^{*} \mathrm{P}<0.05$. All figures were generated from at least three repeated experiments with similar patterns. 


\section{Cellular Physiology $\quad$ Cell Physiol Biochem 2012;30:151-159

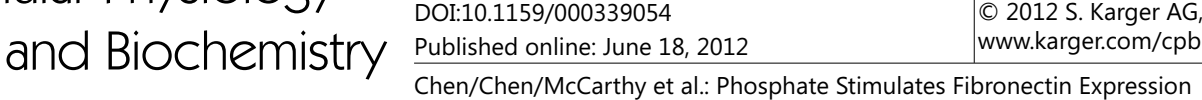

A

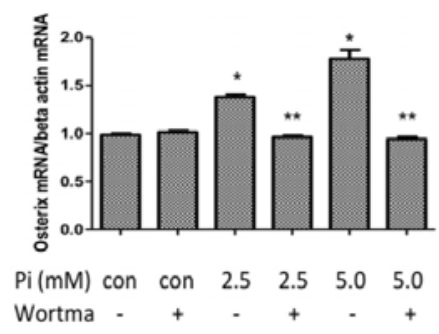

B

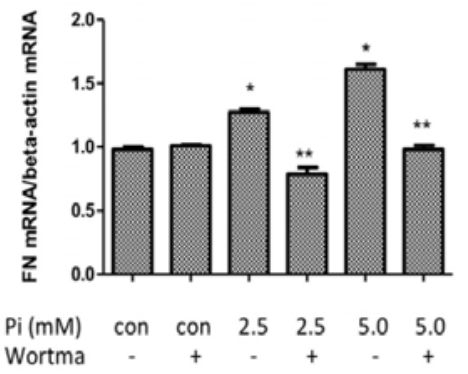

Fig. 3. A: The addition of phosphate to the culture medium increased osterix mRNA levels by $40 \%$ at $2.5 \mathrm{mM}$ and by $75 \%$ at $5 \mathrm{mM}$ phosphate concentration. Treatment of NRK-49F cells with PI3K-Inhibitor Wortmannin $(10 \mu \mathrm{M})$ inhibited phosphate-dependent osterix mRNA increase completely at both the 2.5 and 5.0 $\mathrm{mM}$ phosphate medium concentrations. B: Wortmannin treatment also completely inhibited phosphate-dependent fibronectin mRNA increases at both 2.5 and $5.0 \mathrm{mM}$ phosphate medium concentrations. ${ }^{*}, \mathrm{p}<0.05$ compared to control medium. ${ }^{* *}, \mathrm{p}<0.05$ compared to same medium phosphate concentration but without Wortmannin.
A

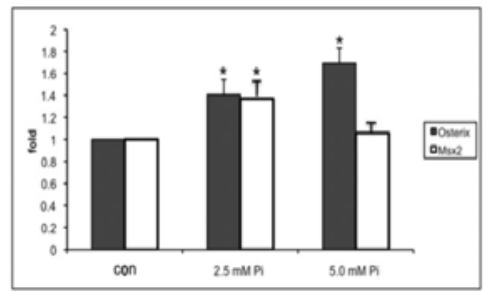

B

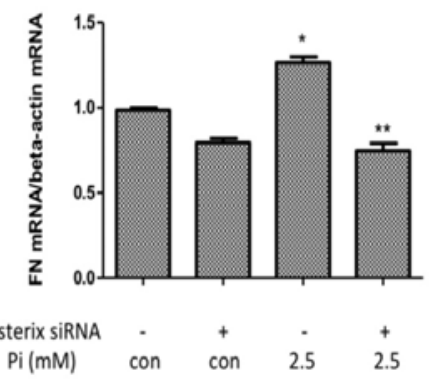

Fig. 4. A: Exposure to 2.5 and $5.0 \mathrm{mM}$ phosphate in cell culture medium increased the mRNA levels of osterix (black bar), a zink finger transcription factor, by $40 \%$ and $75 \%$ respectively in kidney fibroblasts. The mRNA levels of the transcription factor Msx2 (white bar) increased by $39 \%$ at 2.5 $\mathrm{mM}$ phosphate, but only $10 \%$ at $5.0 \mathrm{mM}$ phosphate medium concentration. B:Transfection of the kidney fibroblast cell line with osterix siRNA completely inhibited the increase in fibronectin mRNA seen with $2.5 \mathrm{mM}$ phosphate treatment. *, p<0.05 compared to control medium. ${ }^{* *}, \mathrm{p}<0.05$ compared to same medium phosphate concentration but without Osterix siRNA transfection.

\section{Results}

Phosphate-dependent fibronectin expression

To examine the effect of phosphate on fibronectin synthesis we exposed NRK-49F cells to elevated phosphate medium concentrations. Fibronectin abundance increased in a dosedependent manner as shown in the western blot results of Figure 1A. Fibronectin mRNA levels, determined by real time PCR, increased by $25 \%$ and $60 \%$ in cells exposed to $2.5 \mathrm{mM}$ and $5 \mathrm{mM}$ phosphate (Fig. 1B). Kidney fibroblasts transfected with FN-luciferase promoter construct showed similar increases in luciferase activity, indicating that the increase in fibronectin message was mediated by a stimulatory effect of phosphate on the FN promoter (Fig. 1C).

Signaling pathways induced by phosphate in kidney fibroblasts

Exposure of NRK- $49 \mathrm{~F}$ cells to higher medium phosphate concentrations stimulated the phosphorylation of ERK1/2 and Akt (Fig. 2A). Both p-ERK1/2 and p-AKT abundance was highest in the $5 \mathrm{mM}$ treated group. Pre-treatment of NRK-49F cells with the ERK inhibitor U0126 decreased the level of fibronectin mRNA completely in the $2.5 \mathrm{mM}$ phosphate group, 


\section{Cellular Physiology Cell Physiol Biochem 2012;30:151-159 \\ \begin{tabular}{ll|l} 
and Biochemistry & $\begin{array}{l}\text { DOI:10.1159/000339054 } \\
\text { Published online: June 18, } 2012\end{array}$ & $\begin{array}{l}\text { C } 2012 \text { S. Karger AG, } \\
\text { www.karger.com/cpb }\end{array}$ \\
\cline { 2 - 3 } Chen/Chen/McCarthy et al.: Phosphate Stimulates Fibronectin Expression
\end{tabular}}

Fig. 5. A: Phosphate concentration of $2.5 \mathrm{mM}$ in culture medium increased c-fos mRNA by $175 \%$ within 30 minutes, but had no effect on c-Jun mRNA levels. After 60 minutes of phosphate treatment, c-fos levels had returned back to control levels. B: Exposure to 2.5 and $5.0 \mathrm{mM}$ phosphate increased c-fos mRNA levels by $25 \%$ and $60 \%$ respectively. Transfection of NRK-49F cells with c-fos siRNA decreased the phosphate-induced increase of fibronectin mRNA completely. ${ }^{*}, \mathrm{p}<0.05$ compared to 0 time point. ${ }^{* *}, \mathrm{p}<0.05$ compared to control medium. \#, $\mathrm{p}<0.05$ compared to same medium phosphate concentration but without c-fos siRNA transfection.

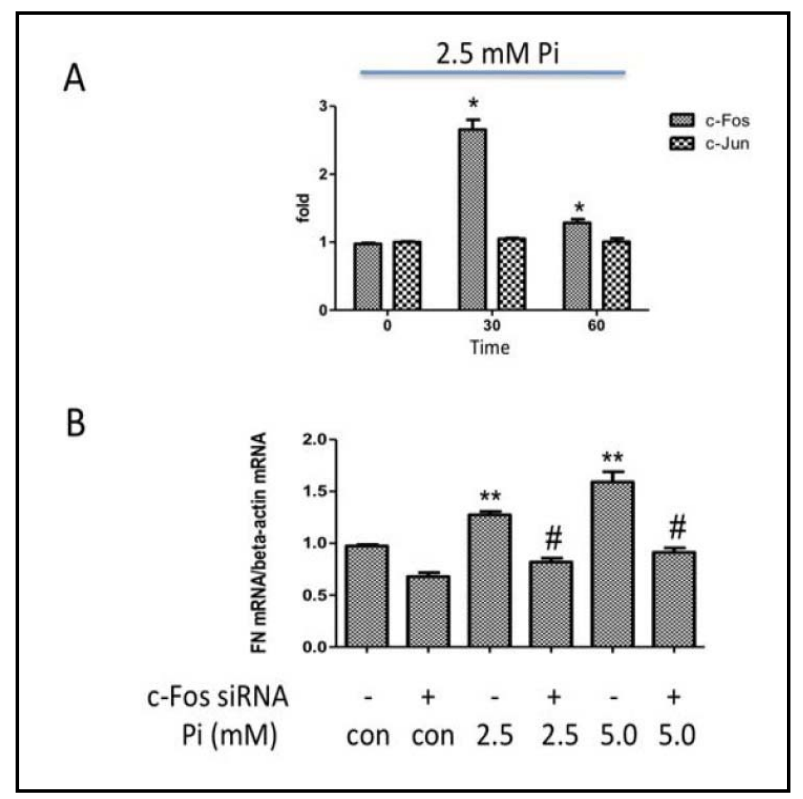

and by $45 \%$ at $5 \mathrm{mM}$ phosphate group (Fig. 2B). Similarly, pre-treatment of NRK-49F cells with the Akt inhibitor Wortmannin, completely inhibited the phosphate-dependent increase in fibronectin mRNA in both $2.5 \mathrm{mM}$ and $5 \mathrm{mM}$ phosphate concentration groups (Fig. 3B).

\section{Transcription factors in phosphate-dependent fibronectin synthesis}

Exposure of kidney fibroblasts to high phosphate concentrations induced a number of transcription factors, such as the zinc finger containing SP family member Osterix and Msx2, which are known to induce matrix production in osteoblasts [25-27]. Osterix mRNA levels were increased following 2.5 and $5.0 \mathrm{mM}$ phosphate exposure by 40 and $75 \%$ respectively (Fig. 4A). Msx2 mRNA levels increased by $40 \%$ at $2.5 \mathrm{mM}$ phosphate exposure, but showed only $10 \%$ increase at $5 \mathrm{mM}$ phosphate (Fig. 4B). Transfection of NRK-49F cells with osterix siRNA prevented the $30 \%$ phosphate-dependent increase in fibronectin mRNA at $2.5 \mathrm{mM}$ exposure. The Akt inhibitor Wortmannin inhibited the phosphate-dependent increase in osterix mRNA completely (Fig. 3A).

Since envolvement of AP-1 transcription factors in progression of renal fibrosis has been shown [28], we examined the stimulatory effect of phosphate on the expression of c-fos and c-jun in NRK-49F cells. Medium concentrations of $2.5 \mathrm{mM}$ phosphate stimulated c-fos mRNA by $175 \%$ within 30 minutes of exposure, while c-jun mRNA levels were only mildly increased (Fig. 5 A). Transfection of NRK-49F cells with c-fos siRNA decreased phosphate-dependent fibronectin stimulation completely (Fig. 5B).

Since NFATc1 has been shown to form transcriptionally active complexes with osterix in osteoblasts [20], we examined the effect of high phosphate medium concentrations on NFATc1 abundance in nuclear and cytoplasmic extracts from NRK-49F cells. 2.5 mM medium phosphate concentrations induced a five-fold increase in nuclear NFATc1 abundance within 30 minutes. $5 \mathrm{mM}$ phosphate stimulated NFATc1 abundance even more. Nuclear NFATc1 levels did not further increase at 60 minutes exposure to high phosphate. Cytoplasmic NFATc1 abudance did not increase following phosphate treatment (Fig. 6A). Treatment of NRK-49F cells with ERK inhibitor U0126 completely diminished the phosphate-dependent increase in NFATc1 (Fig. 6B). To further examine complex formation between osterix and NFATc1, we immunoprecipitated osterix using a NFATc1 antibody. As shown in figure 6C, a steady increase in nuclear abundance of osterix was seen with increasing medium phosphate concentrations. 


\section{Cellular Physiology Cell Physiol Biochem 2012;30:151-159 \\ \begin{tabular}{ll|l} 
and BiOChemistry & $\begin{array}{l}\text { DOI:10.1159/000339054 } \\
\text { Published online: June 18, } 2012\end{array}$ & $\begin{array}{l}\text { C 2012 S. Karger AG, Basel } \\
\text { www.karger.com/cpb }\end{array}$ \\
\cline { 2 - 3 } & Chen/Chen/McCarthy et al.: Phosphate Stimulates Fibronectin Expression
\end{tabular}}

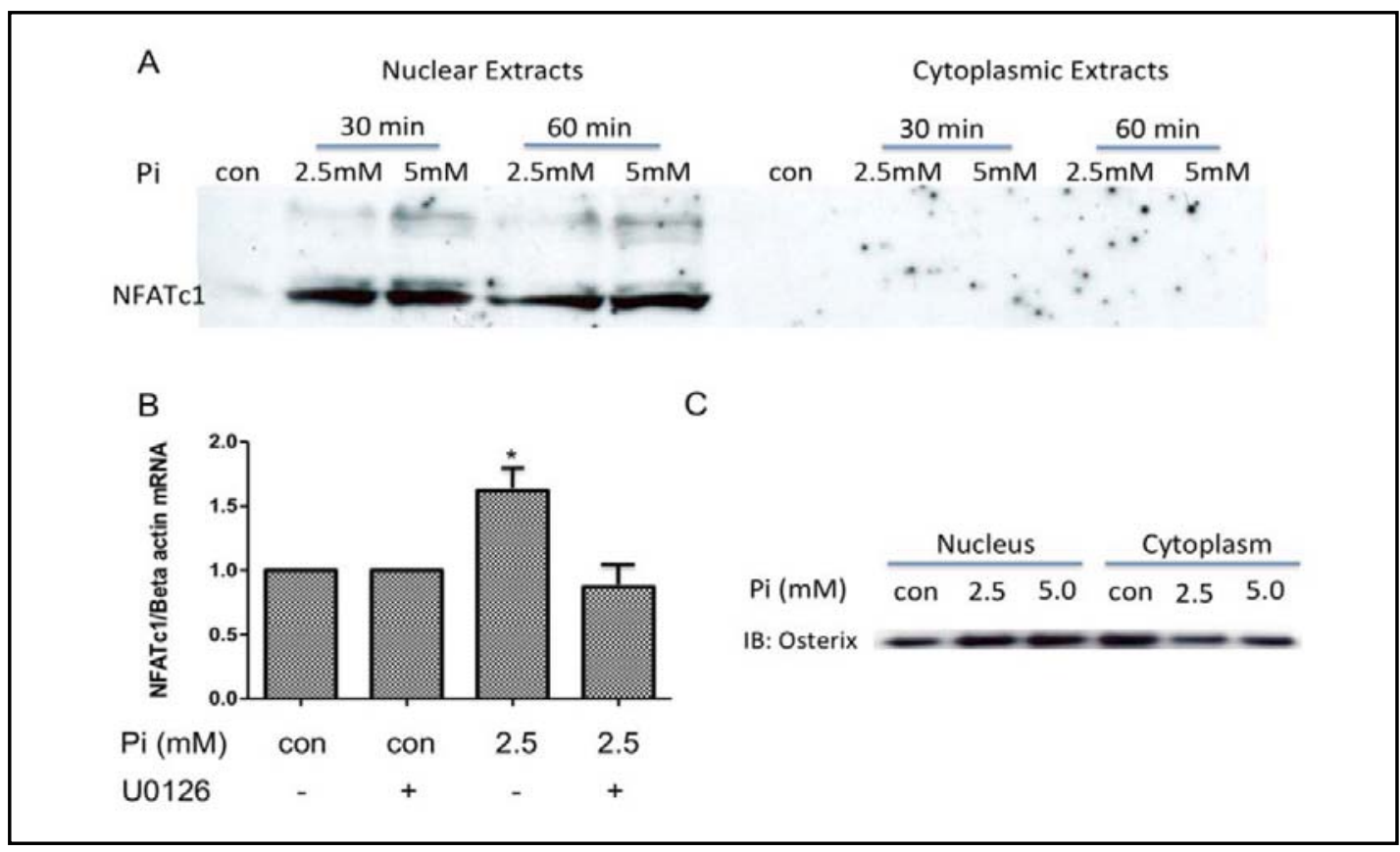

Fig. 6. A: Western blot shows an increase in NFATc1 abundance in nuclear extracts of kidney fibroblasts treated with $2.5 \mathrm{mM}$ phosphate for 30 minutes, compared to controls. Exposure to $5 \mathrm{mM}$ phosphate for 30 minutes increased NFATc1 abundance even further. No further increase of nuclear NFATc1 abundance was seen after 60 minutes of phosphate exposure. Cytoplasmic extracts did not show significant NFATc1 abundance over the same time period. B: NFATc1 mRNA levels increased by $60 \%$ in the $2.5 \mathrm{mM}$ phosphate group compared to controls. The ERK-inhibitor U0126 decreased the NFATc1 mRNA stimulation completely. $*, p<0.05$ compared to control medium. C: Immunoprecipitation of osterix with an anti-NFATc1 antibody from nuclear extracts showed increased abundance after 2.5 and $5.0 \mathrm{mM}$ phosphate treatment. The cytoplasmic fraction showed decreased osterix abundance following the same treatment. ${ }^{*}, \mathrm{p}<0.05$ compared to control medium.

\section{Discussion}

Our results show that fibronectin abundance and message in kidney fibroblasts is enhanced by elevated medium phosphate concentrations. The phosphate-induced increase in fibronectin-promoter activity indicates that phosphate directly stimulates the fibronectin promoter. Since the medium concentrations used in the above described experiments are comparable to a 2 to 4 fold increase of serum phosphate concentrations, our results indicate that even mild increases in serum phosphate concentrations in vivo might have a profound stimulatory effect on fibrogenesis in the kidney. Therefore, mildly elevated serum phosphate levels over a prolonged period of time might lead to accumulation of significant levels of interstitial matrix proteins, such as fibronectin.

Akt and ERK1/2 signaling pathways were stimulated by phosphate in kidney fibroblasts and both induced fibronectin transcription. ERK1/2 has previously been shown to be stimulated by phosphate in an Akt-dependent manner in a human bronchial epithelial cell line [29]. Our findings suggest that ERK1/2 acts down-stream of Akt and induces fibronectin synthesis.

Transcription factors that mediate phosphate-induced fibronectin synthesis in NRK49F cells are Osterix, NFATc1 and c-fos. Osterix mRNA increased significantly following phosphate exposure and inhibition of osterix by siRNA completely suppressed the stimulation of fibronectin. Phosphate-dependent osterix expression was also inhibited by wortmannin, an Akt-specific inhibitor. These findings indicate that Akt stimulates fibronectin synthesis through osterix. 


\section{Cellular Physiology \\ Cell Physiol Biochem 2012;30:151-159 and Biochemistry

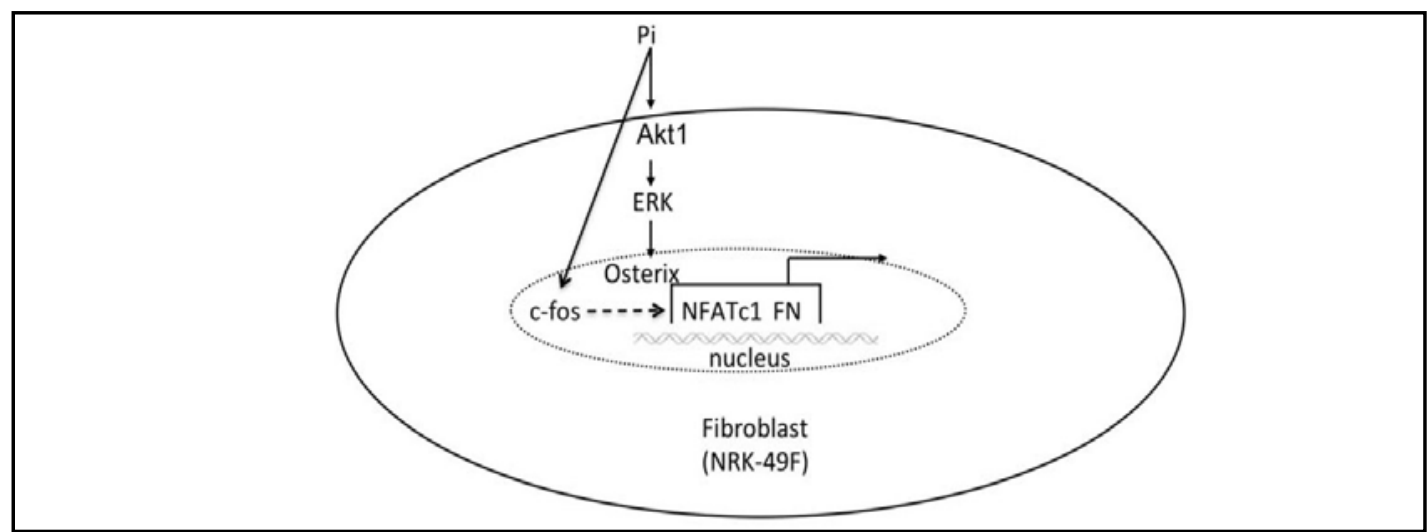

Fig. 7. Signaling pathways and transcription factors involved in phosphate-dependent fibronectin expression in NRK-49F fibroblasts. Arrows demonstrate stimulation.

NFATc1, a member of the NFAT family of transcription factors, showed increased abundance in nuclear extracts of NRK-49F cells following exposure to phosphate. These results indicate that high medium phosphate levels stimulate NFATc1 synthesis in kidney fibroblasts. Immunoprecipitation of Osterix with an anti-NFATc1 antibody showed increased abundace of the nuclear osterix-NFATc1 complex following treatment with high phosphate concentrations. These findings indicate that phosphate stimulates NFATc1 and osterix complex formation, which regulates the synthesis of fibronectin in kidney fibroblasts.

In summary our results show that phosphate stimulates ERK1/2 and Akt1 signaling pathways, which activate the downstream transcription factors osterix and cfos, which through complex formation with NFATc1 mediate fibronectin synthesis in kidney fibroblasts. Figure 7 depicts the hypothetical model of phosphate-dependent stimulation of fibronectin synthesis. Understanding the cell mechanisms of phosphate-dependent fibronectin synthesis in kidney fibroblasts will not only enhance our knowledge of progression of interstitial fibrosis, but will also lead to the development of future drugs to ameliorate this process.

\section{Acknowledgements}

This study was supported by NIDDK RO3 award to GWM.

\section{References}

1 Coresh J, Astor BC, Greene T, Eknoyan G, Levey AS: Prevalence of chronic kidney disease and decreased kidney function in the adult us population: Third national health and nutrition examination survey. Am J Kidney Dis 2003;41:1-12.

2 Bohle A, Strutz F, Muller GA: On the pathogenesis of chronic renal failure in primary glomerulopathies: A view from the interstitium. Exp Nephrol 1994;2:205-210.

3 Voormolen N, Noordzij M, Grootendorst DC, Beetz I, Sijpkens YW, van Manen JG, Boeschoten EW, Huisman RM, Krediet RT, Dekker FW: High plasma phosphate as a risk factor for decline in renal function and mortality in pre-dialysis patients. Nephrol Dial Transplant 2007;22:2909-2916.

4 Delmez JA, Slatopolsky E: Hyperphosphatemia: Its consequences and treatment in patients with chronic renal disease. Am J Kidney Dis 1992;19:303-317.

5 Barsotti G, Morelli E, Cupisti A, Meola M, Dani L, Giovannetti S: A low-nitrogen low-phosphorus vegan diet for patients with chronic renal failure. Nephron 1996;74:390-394. 


\section{Cellular Physiology Cell Physiol Biochem 2012;30:151-159 \\ \begin{tabular}{ll|l} 
and BiOchemistry & $\begin{array}{l}\text { DOI:10.1159/000339054 } \\
\text { Published online: June 18, } 2012\end{array}$ & $\begin{array}{l}\text { (c) 2012 S. Karger AG, Basel } \\
\text { www.karger.com/cpb }\end{array}$ \\
\cline { 2 - 3 }
\end{tabular} \\ Chen/Chen/McCarthy et al.: Phosphate Stimulates Fibronectin Expression}

6 Termorshuizen F, Dekker FW, van Manen JG, Korevaar JC, Boeschoten EW, Krediet RT: Relative contribution of residual renal function and different measures of adequacy to survival in hemodialysis patients: An analysis of the netherlands cooperative study on the adequacy of dialysis (necosad)-2. J Am Soc Nephrol 2004;15:1061-1070.

7 Ibels LS, Alfrey AC, Haut L, Huffer WE: Preservation of function in experimental renal disease by dietary restriction of phosphate. N Engl J Med 1978;298:122-126.

8 Neves KR, Graciolli FG, dos Reis LM, Pasqualucci CA, Moyses RM, Jorgetti V: Adverse effects of hyperphosphatemia on myocardial hypertrophy, renal function, and bone in rats with renal failure. Kidney Int 2004;66:2237-2244.

9 Takeda E, Taketani Y, Morita K, Tatsumi S, Katai K, Nii T, Yamamoto H, Miyamoto K: Molecular mechanisms of mammalian inorganic phosphate homeostasis. Adv Enzyme Regul 2000;40:285-302.

10 Beck GR, Jr., Moran E, Knecht N: Inorganic phosphate regulates multiple genes during osteoblast differentiation, including nrf2. Exp Cell Res 2003;288:288-300.

11 Wang L, Fraley CD, Faridi J, Kornberg A, Roth RA: Inorganic polyphosphate stimulates mammalian tor, a kinase involved in the proliferation of mammary cancer cells. Proc Natl Acad Sci USA 2003;100:1124911254.

12 Jin H, Hwang SK, Yu K, Anderson HK, Lee YS, Lee KH, Prats AC, Morello D, Beck GR, Jr., Cho MH: A high inorganic phosphate diet perturbs brain growth, alters akt-erk signaling, and results in changes in capdependent translation. Toxicol Sci 2006;90:221-229.

13 Nakashima K, Zhou X, Kunkel G, Zhang Z, Deng JM, Behringer RR, de Crombrugghe B: The novel zinc fingercontaining transcription factor osterix is required for osteoblast differentiation and bone formation. Cell 2002;108:17-29.

14 Gao Y, Jheon A, Nourkeyhani H, Kobayashi H, Ganss B: Molecular cloning, structure, expression, and chromosomal localization of the human osterix (sp7) gene. Gene 2004;341:101-110.

15 Hatta M, Yoshimura Y, Deyama Y, Fukamizu A, Suzuki K: Molecular characterization of the zinc finger transcription factor, osterix. Int J Mol Med 2006;17:425-430.

16 Mathew S, Tustison KS, Sugatani T, Chaudhary LR, Rifas L, Hruska KA: The mechanism of phosphorus as a cardiovascular risk factor in ckd. J Am Soc Nephrol 2008;19:1092-1105.

17 Yang TT, Xiong Q, Enslen H, Davis RJ, Chow CW: Phosphorylation of nfatc4 by p38 mitogen-activated protein kinases. Mol Cell Biol 2002;22:3892-3904.

18 Molkentin JD, Lu JR, Antos CL, Markham B, Richardson J, Robbins J, Grant SR, Olson EN: A calcineurindependent transcriptional pathway for cardiac hypertrophy. Cell 1998;93:215-228.

19 Macian F, Lopez-Rodriguez C, Rao A: Partners in transcription: Nfat and ap-1. Oncogene 2001;20:24762489.

20 Koga T, Matsui Y, Asagiri M, Kodama T, de Crombrugghe B, Nakashima K, Takayanagi H: Nfat and osterix cooperatively regulate bone formation. Nat Med 2005;11:880-885.

21 Cobbs SL, Gooch JL: Nfatc is required for tgfbeta-mediated transcriptional regulation of fibronectin. Biochem Biophys Res Commun 2007;362:288-294.

22 Livak KJ, Schmittgen TD: Analysis of relative gene expression data using real-time quantitative pcr and the 2(-delta delta $\mathrm{c}(\mathrm{t})$ ) method. Methods 2001;25:402-408.

23 Bradford MM: A rapid and sensitive method for the quantitation of microgram quantities of protein utilizing the principle of protein-dye binding. Anal Biochem 1976;72:248-254.

24 Zhang L, Chen D, Chen Z, Moeckel GW: Hypertonicity-induced mitochondrial membrane permeability in renal medullary interstitial cells: Protective role of osmolytes. Cell Physiol Biochem 2010;25:753-760.

25 Takahashi T, Kato S, Suzuki N, Kawabata N, Takagi M: Autoregulatory mechanism of runx2 through the expression of transcription factors and bone matrix proteins in multipotential mesenchymal cell line, robc26. J Oral Sci 2005;47:199-207.

26 Lee JS, Lee JM, Im GI: Electroporation-mediated transfer of runx2 and osterix genes to enhance osteogenesis of adipose stem cells. Biomaterials 2011;32:760-768.

27 Wu YF, Matsuo N, Sumiyoshi H, Yoshioka H: Sp7/osterix is involved in the up-regulation of the mouse proalpha1(v) collagen gene (col5a1) in osteoblastic cells. Matrix Biol 2010;29:701-706.

28 Wolf G, Ziyadeh FN, Stahl RA: Angiotensin ii stimulates expression of transforming growth factor beta receptor type ii in cultured mouse proximal tubular cells. J Mol Med (Berl) 1999;77:556-564.

29 Chang SH, Yu KN, Lee YS, An GH, Beck GR Jr., Colburn NH, Lee KH, Cho MH: Elevated inorganic phosphate stimulates akt-erk1/2-mnk1 signaling in human lung cells. Am J Respir Cell Mol Biol 2006;35:528-539. 